\title{
LAW OF SUBSTANCE AND CONSISTENCY OF REGIONAL REGULATION NUMBER 3 OF 2006 CONCERNING COMMUNITY DEVELOPMENT ACTIVITIES IN KARIMAH
}

\author{
Anwar \\ Pascasarjana UIN Sunan Gunung Djati Bandung \\ Email : Anwarrr@gmail.com
}

\begin{abstract}
Laying Islamic Sharia as an agenda of local government is also quite common among the people. Various institutions and activities aimed at campaigning for the "institutionalization" of Islamic Shari'a in public spaces continue to be echoed. With various weaknesses and strengths, one of which is in the district of Cianjur with the Movement for Community Development with morality, the purpose of this article is to see how the consistency of regional regulation number 3 of 2006 applies to regulations issued by the government, both regional and regent regulations, with the analytical research method. Descriptive supported by documents related to the researchers concluded that the regional regulations and the regulations of the regents have not yet optima to incorporate the morality element of karma into each Regulation that is ratified.
\end{abstract}

Keywords: Law, Local Regulations, Society

\section{INTRODUCTION}

Not only at the center, the placement of Islamic Sharia as a regional government agenda is also quite common among the people. Various institutions and activities aimed at campaigning for the "institutionalization" of Islamic Shari'a in public spaces continue to be echoed. With a variety of weaknesses and strengths, community institutions that focus on campaign activities and the implementation of Sharia are established. Even so, the efforts of the public in publicizing the application of Islamic Shari'ah did not find a road that was free of obstacles. Various controversies and rejections also arise from within the community itself with different arguments. However, not a few also doubted or even rejected the application of Sharia as a law (Zoelva, 2015).

But the height of the controversy seems to remain accompanying the government's efforts to make Sharia as one of the frameworks to be stipulated in the policy, especially in legislation. This situation was realized even more quickly when the government regime entered the Reformation era. With the position of the 1945 Constitution amended, the power to form a law that was originally in the hands of the President with the approval of the DPR was changed to the contrary, so more new legal norms were born. Burgerlijk wetboek or the Civil Code The Dutch legacy has been changed so much by various national laws and regulations, especially in the provisions in the field of law and bankruptcy, which are now categorized as economic law (Zoelva, 2015).

The government has also prepared a Bill on the Law of Applied Religious Courts (Syaputra, 2019). This Draft Law is an attempt to transform the rules of Islamic law, as a law that lives in society into positive law. Its scope is the fields of law that become the authority of the Religious Courts. Of course, the legal subject of this positive law will apply specifically to citizens who are Muslim. The President and the House of Representatives also passed the Law on Waqf, which transformed the rules of Islamic law into positive

* Copyright (c) 2019 Anwar

This work is licensed under a Creative Commons Attribution-ShareAlike 4.0 International License. 
IJIK, Vol. 9 No. 1: 9-22

Law Of Substance And Consistency Of Regional Regulation Number 3 Of 2006 Concerning Community Development Activities In Karimah

Anwar

law. Various laws related to business law have also provided an appropriate place for the rules of Islamic law relating to banking and insurance. As a legal system that is believed to be the most complete, Sharia then becomes a special attraction for the figures, observers, researchers and communities of various parts of the world not only as a code that regulates life but furthermore has become part of the global discourse and ideological attraction associated with new world data. This trend is no exception in Indonesia alone; the country is factually inhabited by the majority of the largest Muslims in the world. Various groups of people competing to study and spread ideas and even invite about the need to make the shari'a a new life system that deserves to be chosen (Zoelva, 2015).

If we look at the laws in the field of worship, then practically Islamic law applies without the need to elevate it into positive legal principles (Fauzan \& Fata, 2018), as formalized in the form of legislation. How Islamic law regulates the procedures for carrying out five daily prayers, fasting, and the like does not require positive legal rules. That the five daily prayers are mandatory fardhu'ain according to Islamic law, is not the business of the State. The State cannot intervene and also bargain so that the five daily prayers become mu'akad sunnah, for example. Islamic law in this field directly applies without being intervened by State power. What is needed is a rule that can give Muslims the freedom to carry out the laws of worship, or at most are aspects of the administrative law of the State to facilitate the implementation of a rule of Islamic law (Muwahid, 2012).

Javanese, Sundanese, and Bantenese people develop Islamic law through education, as important subjects in Islamic boarding schools, as well as other places such as Madura. In areas where there are power structures, such as in the kingdom of Mataram, which later broke up into Surakarta and Yogyakarta, religious issues have entered the state bureaucratic structure, Penghulu Ageng at the center of the sultanate, carries out the coordination function for the princes in the district to the villages in carrying out the implementation of worship, and implementation of Islamic law in the field of family and other Civil Code (Zoelva, 2015).

There are no detailed records to ascertain when the Regional Regulations created by the Sharia appeared in Indonesia. But seeing the development of Sharia Regional Regulations began to grow when a long debate about the amendment to the 1945 Constitution in 1999-2002 which also occurred the debate about the enactment of Islamic Sharia in Indonesia. Then it was applied in a special area of NAD. This became even more lively with the increasing push for the implementation of regional autonomy in early 1999. In those years, it could be said to be an era in which the regional government was like a bird that found its freedom until it could do whatever he needs and likes. In the context of freedom, the local government not only began to reform itself structurally but also complemented its bureaucracy with various Regional Regulation products (Zoelva, 2015).

According to Syaukani, who was quoted by Debt Rosidin, there were those who argued that the policy of the implementation of decentralization was also driven by a commitment by the ethnic politics of the colonial government. This opinion is difficult to accept because of the implementation of the regional government, not to advance the local community, but rather is a manifestation of the desire of the colonial government to exploit the colony. This reasoning is reinforced by the fact that in the beginning, the Regulation (staatsbload I 855No.2), which regulates the administration of the colonial government, does not recognize decentralization (Rosidin, 2010).

Islamic scholars are expected to concentrate their ability to realize Islamic systems and Sharia in all aspects of life. They are required to make Islam influential on the social system, state laws, and Islamic education, as Islam has to influence educational institutions, family institutions, and life. They must take on Islam as a whole (Abdullah, 2019). Islamic Sharia is the teachings of Islam in all aspects of life and life. 


\section{IJIK, Vol. 9 No. 1: 9-22}

Law Of Substance And Consistency Of Regional Regulation Number 3 Of 2006 Concerning Community Development Activities In Karimah

Anwar

The presence of Muslims is religion, and the State is an effort to integrity the sacred territory with the temporal region that is believed by Muslims (Arroisi, 2017). This integration was built as a counter concept to the Christian theological system, which had become a political rival rather than theology in the course of the history of power in the world. The integration between religion and State in the doctrine of al-Islam huwa ad-din wa ad-daulah opens harmonious contacts between Islam as a religion and politics so that it is not trapped into a conflict between the two.

Priangan Muslims can be seen in the Cianjur experience. We will see how Wasidi Swastomo, Regent of Cianjur in 2001-2006, was able to exploit unfaithful loyalty to Islamic symbols through the mobilization of ulama figures and various traditional religious authorities. The story begins with the succession process of the Cianjur regent in 2001. Of the many candidates who submitted to the election, Wasidi Swastomo will later be written Wasidi is the only candidate who openly promises to impose "Islamic law" if one day is elected as a regent. A brief story in the election by a very strict member of the Cianjur DPRD, Wasidi Swastomo was finally elected to be the Cianjur Regent 2001-2006 (Syukur, 2011).

The defeat of Wasidi Swastomo in the 2006 elections, apparently did not dampen the steps of Muslim groups to continue to push the furnishing of the Marhamah Gate into a Regional Regulation. Unexpectedly, the newly elected Regent of Cianjur, Tetjep Muhtar Sholeh, turned out to have supported the discussion of the Marhamah Gate Regional Regulation Draft. The reason is that the Marhamah Gate Regional Regulation has been discussed by the DPRD in the previous period, and there is not enough reason to stop it (MA'MUN, 2016). Finally, the Marhamah Gate Regional Regulation was finally approved as Regional Regulation No. 3 Tahur 2006 on July 20, 2006. There are 12 (twelve) fields that are regulated therein, namely the fields of morality, worship, government, politics, education, preaching, economics, society, law, arts and culture, the environment, and coaching and development. Following the stipulation of Regional Regulation No. 3/2006 concerning the Marhamah Gate, the Regional Regulation on the Marhamah Gate has become a living law that develops in the community and let it continue so without the need to be regulated by a Regional Regulation (Syukur, 2011).

On I Muharram 1422 Hijri or March 26, 2001, the Islamic Community of Cianjur, which amounted to $99 \%$ of 1,931,394 inhabitants in the 2000 population census represented by the Cianjur Regency MUI and 35 Islamic CSOs signed a joint agreement containing three matters: First: believe in Islamic shari'ah is living guidelines and solutions to multidimensional crisis relief that hit the Indonesian nation and the road to the world and hereafter happiness. Second: intending to carry out Islamic Shariah in a Kaaffah and gradually in daily life both personally and in society in Cianjur Regency. And Third, asking the Regent of Cianjur and the District Parliament of Cianjur to follow up on the aspirations of the Islamic Community of Cianjur district.

This Regional Regulation applies legal products that exist at the provincial or district/city level. Regional Regulation on the Gate of Marhamah was born at the time of the general election in Cianjur Regency because at that time wanted the direct election of the first Regent and deputy regent. Then this Regional Regulation indirectly became a political issue in the first election in Cianjur Regency in 2005.

Regional regulations are provincial or district/city level regional legal products (Goni, 2015). Local Regulations are rules that are made by the government for the community, open as a political tool by the political elite, the establishment of this regional Regulation only costs money. Because it is unclear the purpose and what is produced by the regional Regulation, if we look at the Marhamah Gate Regional Regulation in the form of norms or recommendations, if people do not carry out, there are no clear sanctions. 
IJIK, Vol. 9 No. 1: 9-22

Law Of Substance And Consistency Of Regional Regulation Number 3 Of 2006 Concerning Community

Development Activities In Karimah

Anwar

\section{RESEARCH METHOD}

The research method is a descriptive method that is, a method in examining the status of a human group, an object, a condition, a system of thought, or a class of events in the present, the purpose of this descriptive research is to make a descriptive, systematic, factual and descriptive picture. Accurate facts, properties, and relationships between the phenomena investigated. Meanwhile, according to Whitney, as quoted by Moh Nazir, the descriptive method is the search for facts with the correct interpretation (Nazir, 2011).

The method used is descriptive and can be interpreted as a procedure for solving the present based on the facts that appear, or as they are. The author would like to know about the substance, consistency, and effectiveness of regional regulations No. 3 of 2006 concerning the community development movement good behavior (akhlakul karimah) in Cianjur regency in the form of problem area regulation, which is investigated by describing or describing the State of the subject or object of research No. 3 of 2006 concerning the movement of community development ahlakul karimah (Nazir, 2011).

\section{RESULT AND DISCUSSION}

\section{Substance and Consistency of Regional Regulation Number 3 the Year 2006 Concerning Movement for Developing Berahlakul Karimah Community in Cianjur Regency.}

Menurur K.H. Khoerul Anam, who is a Religious Representative Office in Cianjur Regency, regarding the contents of the Regional Regulation, how Islamic values enter the government system in Cianjur Regency, can be seen that Regional Regulation No. 3/2006 is the result of the Cianjur Regency Ulama to conduct moral guidance in the government, can be seen from each of these articles, how Islamic values are included in regional regulations (Sukayat, 2015). The regional Regulation regulates various fields, namely the Ahklak Field, the Worship Field, the Government Field, the Politics Field, the Education Field, the Da'wah Field, the Economy Field, the Social Field, the Law Field, the Cultural Arts Field, the Environment Field, the Field of Development and Development

Regarding the substance of Regional Regulation No. 3/2006 concerning Karimah's Community Development Movement above, which is known as Gerabang Marhamah, the writer after conducting a research on the Regional Regulation, aims to create all government apparatuses and the public, to be honest, and have good character (noble) to carry out development. In Cianjur Regency.

The contents of the Regional Regulation regulate various sapek in the life of Cianjur Regency community, it can be seen from the Regional Regulation namely the Field of Worship, governance, politics, Education, da'wah, Economy, Society, Law, Cultural Arts, Environment, because humans cannot be separated from various fields above in everyday life

In the substance of this Regional Regulation, how Islamic values participate in the development of the Cianjur Regency, morality is very important in Islam, with the issuance of this Regional Regulation where Islamic values can enter the government system and social life of the community to carry out development in Cianjur Regency.

Regional Regulation is a legal product issued by the government of Cianjur Regency, for all communities in Cianjur Regency, based on article 1 point 9, it states

"Society is a group of people domiciled in Cianjur Regency."

Seeing the article above said domiciled, is a person who is proven by identification or identification card resident in Cianjur Regency or settled in Cianjur Regency, both those who are Muslim or non-Muslim. 
IJIK, Vol. 9 No. 1: 9-22

Law Of Substance And Consistency Of Regional Regulation Number 3 Of 2006 Concerning Community

Development Activities In Karimah

Anwar

Islam, this Regional Regulation does not apply to people who do not have a Cianjur regency identity card, this Regional Regulation does not recognize ethnicity, gender, race, or class of origin of the community or people who have a Cianjur Regency KTP.

The substance of Regional Regulation Number 3 of 2006 Concerning the Movement for the Development of the Community with the Right of Karimah, only Muslims who know Akhlakul Karimah, non-Muslim people do not know or know the principles contained in the Qur'an and the Sunnah of the Prophet Muhammad. These regional regulations are difficult to implement even in contradiction with human rights for those who are not Muslim the role is very important and has a position in the religion of Islam so that every aspect of the life of Islamic teachings always aims at the formation of character and the formation of noble character or known as good behavior. The best believer said the Prophet Muhammad, is the person who is the most moral, and the person who is the most Islamic is a human being or the person who is the most moral.

The article above Morals in the concept of Islamic religion can not be equated with ethics; if ethics is a branch of philosophy that limits the matters of courtesy between fellow people or humans, then Moral is broader in scope and meaning. Morals, in addition to regulating the relationship between fellow humans, morality also regulates his relationship with God, even human relations with nature and the environment.

Islamic Religion regarding Tabi'at, attitudes, and behavior or habits in accordance with Islamic principles. How can non-Islamic societies accept Tabi'at, attitudes, and behavior or habits that are in accordance with Islamic principles? Because this Regional Regulation applies not only to the Islamic community but all people who are inhabited or who have a Cianjur regency identity card, while nonIslamic people who do not know Islamic taboos, attitudes, and principles. It is necessary to explain the guidelines, principles, guidance, values , and mission of Akhlakul Karimah as can be accepted by nonMuslims because there are several articles such as the article below:

Article 3, Article 5, Article 6, Article 7 Paragraph (2), Article 8 Paragraph (1), Article 9, Article 10, Article 11, and Article 12. Because this article is not expressly regulated regarding the principle of principles of Akhlakul Karimah. There needs to be socialization regarding the principles of Akhlakul Karimah, which is shown to the Islamic community only but to non-Islamic communities who live in the Cianjur Regency.

\section{Effectiveness of Regional Regulation Number 3 of 2006 concerning the Berahlakul Karimah Community Development Movement in Cianjur Regency.}

Legal effectiveness is the success of the law to achieve goals. Effectiveness is defined as something or conditions which are in accordance with the targets or objectives to be pursued or expected. The law is said to be effective if citizens behave as expected or desired by the law.

Considering that regional regulations are political products, local political policies can affect the effectiveness of these regional regulations. Regional Regulation Number 3 of 2006 concerning the Movement of Community Development for Good behavior In Cianjur Regency, it emerged during the reign of Wasidi Swastomo, namely the Regent of Cianjur in the period of 2001 to 2006, when it was still in the form of the Cianjur Regent's policy, this Regional Regulation was also an initiative of the Cianjur Regent at that time. When the draft of this Regional Regulation was submitted to the Cianjur District Representative Council at that time, there was a general election of the Regent. This Regional Regulation was passed, having replaced the regional head, namely Tjetjep Muhtar Soleh.

The author tries to measure the effectiveness of these Regional Regulations with regional law products or regional policies whether each formation of regional law products or Regents 
IJIK, Vol. 9 No. 1: 9-22

Law Of Substance And Consistency Of Regional Regulation Number 3 Of 2006 Concerning Community

Development Activities In Karimah

Anwar

Regulations whether Regional Regulation Number 3 of 2006 concerning the Movement of Community Development Good behavior becomes a reference or a juridical basis in its making because these Regional Regulations regulate various in the social life of the community both at the government and community level.

Regarding the worship section of article 4, the author did not find any legal product in the form of regional regulations and regent regulations after the enactment of this regional Regulation from 2006 to 2015, but the author saw that there were regional regulations relating to the above article in the worship sector, but regional regulation number 3 the year 2006 Regarding the Movement for Community Development Good behavior is not used as a basis for law or repercussions in its consideration, we can see below the Legal product regarding the Field of Worship. In the Field of Worship, the writer does not find any Regional Regulation relating to the Field of Worship.

Table 1. Regulations of the Regent relating to the Field of Worship

\begin{tabular}{|c|c|l|c|}
\hline No & $\begin{array}{c}\text { Number and Year of } \\
\text { Regent Regulations }\end{array}$ & \multicolumn{1}{|c|}{ Content } & Note* \\
\hline 1 & 05 of 2008 & $\begin{array}{l}\text { Forum for Religious Harmony (Forum Kerukunan Umat Beragama } \\
\text { (FKUB)) }\end{array}$ & No \\
\hline 2 & 06 of 2008 & $\begin{array}{l}\text { Guidelines for the Establishment of Village / Kelurahan Libraries and } \\
\text { Sub-District Great Mosque Libraries }\end{array}$ & No \\
\hline 3 & 20 of 2013 & $\begin{array}{l}\text { Procedure for Expanding Hajj Pilgrimage Departure and Return } \\
\text { Costs }\end{array}$ & No \\
\hline
\end{tabular}

Data Source: Regional Secretariat of Legal Section of Cianjur Regency

Note: Yes: Used as a juridical basis in making regional legal products

No: Not used as a legal basis in the manufacture of regional legal products

\section{Regional Regulation No. 3/2006 concerning the Good Behavior Community Development Movement, Part 3 in Government Section article 5 states:}

1. Ahlaqul Karimah (Good Behavior) is a guideline and reference for regional governments and government officials and other legal entities in determining each policy and decision.

2. Every local government policy is expected to prevent all forms of activities that result in damage to Ahlaq.

Regarding the governmental sector above, the writer did not find a legal product, in the form of regional regulations and regent regulations after the enactment of this regional Regulation from 2006 to 2015 , the author sees 54 regional regulations and 192 regent regulations relating to the above article in the government sector, but regional regulations no. 3 of 2006 concerning the Movement of Community Development for Berahlakul Karimah is not used as a legal or juridical basis in its consideration,

In the contents of Regional Regulation Number 3 of 2006 concerning the Movement of Community Development with Good Behavior, the fourth part of the Political Section article 6 states: 
IJIK, Vol. 9 No. 1: 9-22

Law Of Substance And Consistency Of Regional Regulation Number 3 Of 2006 Concerning Community

Development Activities In Karimah

Anwar

"Every person, legal entity, political institution, a political institution in conveying political aspirations or political decision making refers and is guided by the values of Akhlakul Karimah (Good Behavior)"

Regarding the effectiveness of the Political Field according to article 6 above, the author did not find a legal product in the form of Regional Regulations and Regents Regulations from 2006 to 2015, the authors see there are 2 Regional Regulations and 3 Regents Regulations relating to the above article, still, Regional Regulation Number 3 of 2006 on the Movement of Community Building for the Karimah Endorsed People is not used as a basis for law or repercussions in its consideration,

Table 2. Legal products regarding Politics.

\begin{tabular}{|l|l|l|l|}
\hline No & $\begin{array}{l}\text { Number and Year of } \\
\text { Regional } \\
\text { Regulation }\end{array}$ & Content & Note* \\
\hline 1 & 05 of 2006 & $\begin{array}{l}\text { Procedure for Nominating, Election, Appointment and } \\
\text { Dismissal of Regional Heads }\end{array}$ & None \\
\hline 2 & 13 of 2007 & $\begin{array}{l}\text { Guidelines for Submitting, Submitting and Reporting } \\
\text { the Use of Financial Aid to Political Parties }\end{array}$ & None \\
\hline
\end{tabular}

Data Source: Regional Secretariat of Legal Section of Cianjur Regency

Note: Yes: Used as a juridical basis in making regional legal products

None: Not used as a legal basis in the manufacture of regional legal products

Table 3. Regent Regulations relating to the Political Field as follows:

\begin{tabular}{|l|l|l|l|}
\hline No & $\begin{array}{l}\text { Number and Year of } \\
\text { Regent Regulations }\end{array}$ & Content & Note* \\
\hline 1 & 11 of 2008 & Political Services of the Cianjur Regency Government & No \\
\hline 2 & 23 of 2010 & $\begin{array}{l}\text { Duties, Functions, and Work Procedures of } \\
\text { Organizational Units within the Office of National Unity } \\
\text { and Community Protection }\end{array}$ & No \\
\hline 3 & 07 of 2012 & $\begin{array}{l}\text { Duties, Functions and Work Procedures of } \\
\text { Organizational Units within the National Unity Agency } \\
\text { and Community Protection }\end{array}$ & No \\
\hline
\end{tabular}

Data Source: Regional Secretariat of Legal Section of Cianjur Regency

Note: Yes: Used as a juridical basis in making regional legal products

None: Not used as a legal basis in the manufacture of regional legal products

\section{In Regional Regulation No. 3/2006 concerning the Good Behavior Community Development Movement in Cianjur Regency, the fourth article in the Education Sector article 7 states:}

1. Education is directed to nurture pious children who believe and have faith in mastering science and technology to embody the sakinah family and the community of marhamah in accordance with the objectives of national education

2. Every formal education institution, formal and informal nom in the implementation of education integrates the values of Akhlakul Karimah

3. Every Islamic student must follow religious education carried out by madrasa diniah, Islamic boarding schools, or similar religious education institutions.

4. The implementation of the certificate referred to in paragraph (3) shall be further regulated by the Regent 
IJIK, Vol. 9 No. 1: 9-22

Law Of Substance And Consistency Of Regional Regulation Number 3 Of 2006 Concerning Community

Development Activities In Karimah

Anwar

Regarding the effectiveness of the Education Sector above, the author looks at 2 legal products in the form of 1 Regional Regulation and 1 of the Regents Regulations, which relate to education from 2006 to 2006, Regional Regulation Regarding Karimah Community Development Movement being made a consensus, we can see below regarding Legal products in the Field of Education.

Table 4. Regional Regulation Data relating to the Field of Education

\begin{tabular}{|l|l|l|l|}
\hline No & $\begin{array}{l}\text { Number and Year of } \\
\text { Regional Regulation }\end{array}$ & Content & Note* \\
\hline 1 & 03 of 2014 & $\begin{array}{l}\text { Empowerment of Diniyah Takmiliyah } \\
\text { Education and Qur'anic Education }\end{array}$ & Yes \\
\hline
\end{tabular}

Data Source: Regional Secretariat of Legal Section of Cianjur Regency

Note * Available: Used as a legal basis in the manufacture of regional legal products

None: Not used as a legal basis in the manufacture of regional legal products

\section{Regional Regulation No. 3/2006 concerning the Good Behavior Community Development Movement, the fourth part of the Da'wah Section article 8 states:}

1. The regional government and community together develop and develop Da'wah Islamiah within the framework of the development of the Berakhlakul Karimah community.

2. Da'wah institutions/bodies are directed to have scientific insights to give birth to believers and pious people and to master science and technology.

Regarding the effectiveness of the Da'wah Field in article 8 above, the author did not find a Legal product in the form of a Regional Regulation relating to the Da'wah Field article 8, whereas for 2 Regents Regulations from 2006 to 2015, Regional Regulation Number 3 of 2006 concerning Development Movement Kariakh Berahlakul society, is not used as a basis for law or repercussions in its constituents, we can see below the product of law regarding the Da'wah Field.

Table 5. Regional Regulations relating to the Da'wah Sector

\begin{tabular}{|l|l|l|l|}
\hline No & $\begin{array}{l}\text { Number and Year of } \\
\text { Regent Regulations }\end{array}$ & Content & Note* $^{*}$ \\
\hline 1 & 01 of 2010 & $\begin{array}{l}\text { Implementation Guidelines for Regional Regulation } \\
\text { Regarding Zakat Management }\end{array}$ & None \\
\hline 2 & 35 of 2011 & Management of Da'wah Building and Hajj Dormitory & None \\
\hline
\end{tabular}

Data Source: Regional Secretariat of Legal Section of Cianjur Regency

Note: Yes: Used as a juridical basis in making regional legal products

None: Not used as a legal basis in the manufacture of regional legal products

\section{Regional Regulation No. 3/2006 concerning the Good Behavior Community Development Movement, Seventh Part in Economics Article 9 states:}

1. The regional government regulates and directs the implementation of economic activities as well as all forms of activities related to the economy in the life of the community in accordance with the guidance of the Akhlakul Karimah in a gradual and sustainable manner.

2. The regional government, together with the community, must support and develop and create jobs and businesses that are Good Behavior.

Regarding the effectiveness of the economy above, the author did not find a Legal product in the form of Regional Regulations and Regents Regulations from the year after they were ratified, this Regional 
IJIK, Vol. 9 No. 1: 9-22

Law Of Substance And Consistency Of Regional Regulation Number 3 Of 2006 Concerning Community

Development Activities In Karimah

Anwar

Regulations from 2006 to 2015, but the author sees that there are 6 Regional Regulations and 36 Regents Regulations relating to the above article, in Article 9 of Regional Regulation No. 3/2006 concerning the community development movement Berakhlakul karimah, is not used as a legal basis in the formation of regional legal products, we can see below the Legal products relating to the economy in article 9.

Table 6. Regional Regulations relating to the economy

\begin{tabular}{|l|l|l|l|}
\hline No & $\begin{array}{l}\text { Number and Year } \\
\text { of } \begin{array}{l}\text { Regional } \\
\text { Regulation }\end{array}\end{array}$ & Note* \\
\hline 1 & 02 of 2007 & Regional Financial Management & None \\
\hline 2 & 10 of 2012 & Levies on the Use of Regional Wealth & None \\
\hline 3 & 11 of 2012 & Slaughterhouse levies & None \\
\hline 4 & 12 of 2012 & Building Permit Retribution & None \\
\hline 5 & 13 of 2012 & Disturbance Permit Retribution & None \\
\hline 6 & 05 of 2013 & $\begin{array}{l}\text { Regional Equity Participation in Regional Government } \\
\text { Companies in the District of Cianjur District }\end{array}$ & None \\
\hline
\end{tabular}

Data Source: Regional Secretariat of Legal Section of Cianjur Regency

Note: Yes: Used as a juridical basis in making regional legal products

None: Not used as a legal basis in the manufacture of regional legal products

\section{Regional Regulation Number 3 of 2006 concerning Community Development Movements has Good Behavior, the eighth part in the Social Field in article 10 states:}

1. The government and the community together develop and develop community life with the morality of Karimah.

2. Community activities give priority to elevating the dignity and interests of the community as subjects of state administration through fostering programs that have the character of Karimah

Regarding the effectiveness of the Community Sector above, the author did not find any legal product in the form of Regional Regulations and Regents Regulations, after the ratification of Regional Regulation No. 3/2006 relating to the above article in the Community Sector, but there are 2 Regional Regulations and 5 Regents Regulations relating to Regional Regulations No. 3 In 2006. However, the Regional Regulation was not made into a Law product or Legal basis in consideration of making the Regional Regulation, we can see below the Legal product regarding the Social Field in article 10.

Table 7. Regional Regulations relating to the Field of Society

\begin{tabular}{|l|l|l|l|}
\hline No & $\begin{array}{l}\text { Number and Year } \\
\text { of Regional } \\
\text { Regulation }\end{array}$ & Content & Note* \\
\hline 1 & 08 of 2006 & Social Institution & None \\
\hline 2 & 35 of 2011 & $\begin{array}{l}\text { Placement and Protection of Indonesian } \\
\text { Workers in Cianjur Regency Overseas }\end{array}$ & None \\
\hline
\end{tabular}

Data Source: Regional Secretariat of Legal Section of Cianjur Regency

Note: Yes: Used as a juridical basis in making regional legal products None: Not used as a legal basis in the manufacture of regional legal products

Table 8. Regulations of the Regent relating to the Field of Society 
IJIK, Vol. 9 No. 1: 9-22

Law Of Substance And Consistency Of Regional Regulation Number 3 Of 2006 Concerning Community

Development Activities In Karimah

Anwar

\begin{tabular}{|l|l|l|c|}
\hline \hline No & $\begin{array}{l}\text { Number and Year } \\
\text { of } \begin{array}{l}\text { Regent } \\
\text { Regulations }\end{array}\end{array}$ & Content & Note* \\
\hline 1 & 08 of 2008 & $\begin{array}{l}\text { System and Procedure of Grant Expenditure, Subsidies and } \\
\text { Regional Expenditures }\end{array}$ & None \\
\hline 2 & 23 of 2013 & $\begin{array}{l}\text { Amendment to Regent Regulation Number 27 of 2011 } \\
\text { concerning Procedures for Budgeting Implementation and } \\
\text { Administration, Accountability and Reporting, and Monitoring } \\
\text { and Evaluation of Grant Expenditures and Social Assistance } \\
\text { Spending sourced from APBD }\end{array}$ & None \\
\hline 3 & 14 of 2011 & $\begin{array}{l}\text { Directions for Implementing Regional Regulation Number 03 } \\
\text { Year 2010 Regarding Combating Trafficking in Persons }\end{array}$ & None \\
\hline 4 & 15 of 2011 & Guidelines for Integrated Service Post Management & None \\
\hline 5 & 20 of 2014 & Guidelines for Implementing Gender Decoding & None \\
\hline & Data Source: Regional Secretariat of Legal Section of Cianjur Regency \\
& Note: Yes: Used as a juridical basis in making regional legal products & \\
\hline
\end{tabular}

\section{Regional Regulation No. 3/2006 concerning the Karimah Khulul Community Development Movement, the ninth section in the Field of Law in article 10 states:}

1. Each regional law product is directed and or adjusted to the values of the Akhlakul Karimah

2. Law enforcement, both based on Regional Regulations and or other laws and regulations are carried out with due regard for a sense of justice in accordance with the principles of Akhlakul Karimah.

Legal Products in the form of Regional Regulations and Regents Regulations from the Year after the implementation of these Regulations from 2006 to 2015. The author sees that there are several Regional Regulations relating to the article above in the Field of Society, including 5 Regional Regulations and 4 Regents Regulations relating to Regional Regulations Number 3 of 2006 concerning the Karimah Community Development Movement, not used as a legal basis or reference in its consideration, we can see below the Legal Products in the Field of Law in article 10.

Table 9. Regional Regulations relating to the Legal Field

\begin{tabular}{|l|l|l|l|}
\hline No & $\begin{array}{l}\text { Number and Year } \\
\text { of } \begin{array}{l}\text { Regional } \\
\text { Regulation }\end{array}\end{array}$ & Content & Note* \\
\hline 1 & 03 of 2010 & Counter Trafficking in Persons & None \\
\hline 2 & 04 of 2013 & Procedure for Forming Regional Legal Products & None \\
\hline 3 & 07 of 2013 & Implementation and Management of Social Welfare & None \\
\hline 4 & 12 of 2013 & Prohibition of Distribution and Sales of Alcoholic Beverages & None \\
\hline 5 & 13 of 2013 & $\begin{array}{l}\text { Community Disease Control and Management in Cianjur } \\
\text { Regency }\end{array}$ & None \\
\hline
\end{tabular}

Data Source: Regional Secretariat of Legal Section of Cianjur Regency

Note: Yes: Used as a juridical basis in making regional legal products None: Not used as a legal basis in the manufacture of regional legal products 
IJIK, Vol. 9 No. 1: 9-22

Law Of Substance And Consistency Of Regional Regulation Number 3 Of 2006 Concerning Community

Development Activities In Karimah

Anwar

\section{Regional Regulation No. 3/2006 concerning the Good Behavior (Akhlakul Karimah) Community Development Movement, the ninth section of Art and Culture in article 10 states:}

1. Fostering the development and preservation of traditional and modern art and culture directed at creations that carry the Karihl Akhlakul Mission

2. Performing arts or cultural performances, as referred to in paragraph (1) may not be contrary to the ideals of Akhlakul Karimah.

Regarding the effectiveness of the Arts and Culture above, the author found a Law product related to Cultural Arts in the form of 1 Regent Regulation from 2006 to 2015, but the author sees no legal basis in establishing this Regent Regulation, we can see below this Legal product regarding Field of Cultural Arts in article 12 .

Tabel 10. Peraturan Daerah yang berkaitan dengan Bidang Seni Budaya

\begin{tabular}{|l|l|l|l|}
\hline No & $\begin{array}{l}\text { Number and Year } \\
\text { of } \\
\text { Regulations }\end{array}$ & Content & Note* \\
\hline 1 & 51 of 2014 & $\begin{array}{l}\text { Establishment of Organization and Work } \\
\text { Procedure of the Technical Implementation Unit } \\
\text { of the Tourism Area Office in the Culture and } \\
\text { Tourism Office of Cianjur Regency }\end{array}$ & None \\
\hline
\end{tabular}

Data Source: Regional Secretariat of Legal Section of Cianjur Regency

Note: Yes: Used as a juridical basis in making regional legal products

None: Not used as a legal basis in the manufacture of regional legal products

\section{Regional Regulation Number 3 of 2006 concerning the good behavior community development movement, section eleven in the Environmental Section article 12 states:}

1. Everyone is required to preserve the environment.

2. The government must encourage and control the preservation of the environment.

Regarding the effectiveness of the environment above, the author did not find a legal product in the form of regional regulations and regulation regulations from the year after the enactment of regional regulation number 3 of 2006, legal products ranging from 2006 to 2015. But the authors found eight regional regulations and 60 district regulations relating to Environmental sector Article 13 Regional Regulation No. 3/2006 concerning the Karimah-based Community Development Movement, but Regional Regulation No. 3/2006 is not used as a basis for law or repercussions in its consideration. We can see below the Law on Environmental Products in article 13.

Table 11. Local Regulations relating to the Field of Environment

\begin{tabular}{|l|l|l|l|}
\hline No & $\begin{array}{l}\text { Number and Year } \\
\text { of } \\
\text { Regulation }\end{array}$ & Content & Note* \\
\hline 1 & 04 of 2006 & Environmental Study & None \\
\hline 2 & 05 of 2010 & Implementation of Fisheries Affairs & None \\
\hline 3 & 07 of 2011 & $\begin{array}{l}\text { Establishment of Traditional Markets, Modern Shopping } \\
\text { Centers and Tooks }\end{array}$ & None \\
\hline 4 & 01 of 2013 & Telekon Communications Tower Control in Cianjur Regency & None \\
\hline
\end{tabular}


IJIK, Vol. 9 No. 1: 9-22

Law Of Substance And Consistency Of Regional Regulation Number 3 Of 2006 Concerning Community Development Activities In Karimah

Anwar

\begin{tabular}{|l|l|l|l|}
\hline \hline 5 & 14 of 2013 & Building & None \\
\hline 6 & 15 of 2013 & Electricity & None \\
\hline 7 & 16 of 2013 & Regional Mining and Energy Affairs Agency & None \\
\hline 8 & 06 of 2014 & Local water company & None \\
\hline
\end{tabular}

Data Source: Regional Secretariat of Legal Section of Cianjur Regency

Note: Yes: Used as a juridical basis in making regional legal products

None: Not used as a legal basis in the manufacture of regional legal products

Regarding the effectiveness of Regional Regulation Number 3 of 2006 concerning the Movement for the Development of the Community in the District of Karimah in Cianjur Regency, that this Regional Regulation is ineffective, the author after seeing the data in the Legal Section of Cianjur Regency has nothing to do with this Regional Regulation, Regional Regulation Number 3 of 2006 regulate the entire life of society and government in general. This Regional Regulation is not used as a legal basis in the consideration for the formation of regional law products in Cianjur Regency, both Regional Regulations and Regents Regulations.

According to Muhammad Toha as a member of the House of Representatives of Cianjur regency from 2003 until now said "that Regional Regulation Number 3 of 2006 concerning the community development movement is not as expected, in the implementation of this Regional Regulation only exists in the Field of Education only in its implementation namely the Regulations of the Regent governing Early Madrasas or In-formal Education only, not all of the Fields in Regional Regulation Number 3 of 2006, in the Education Sector there is a joint decree between the head of the department and the office of the Cianjur regency's ministry of religion which regulates the provisions for learning of takahili early education and Qur'anic education in 2012. While other parts, there is no Regent Regulation that follows up on Regional Regulation Number 3 of 2006. According to him, the change of Regent also changed his policy. Because Regent Regulation Number 3 of 2006 was the initiative of the previous Regent, namely Mr. Ir. Wasidi Swastomo, which was validated during the reign of Drs. Tjetjep Muhtar Soleh, the current Regent.

Table 12. Data on the number of Regional Regulations and the number of Regents Regulations, Number and Year

\begin{tabular}{|c|c|c|c|c|}
\hline \multirow[b]{2}{*}{ No } & \multirow[b]{2}{*}{ Year } & \multicolumn{3}{|l|}{ total } \\
\hline & & $\begin{array}{l}\text { Regiona } \\
\text { Regents }\end{array}$ & Regulations Regents & $\begin{array}{l}\text { Regional Regulations Regents } \\
\text { Regents }\end{array}$ \\
\hline 1 & 2006 & & 12 & 28 \\
\hline 2 & 2007 & & 7 & 21 \\
\hline 3 & 2008 & & 7 & 19 \\
\hline 4 & 2009 & & 3 & 55 \\
\hline 5 & 2010 & & 12 & 69 \\
\hline 6 & 2011 & & 11 & 36 \\
\hline 7 & 2012 & & 13 & 45 \\
\hline 8 & 2013 & & 17 & 40 \\
\hline 9 & 2014 & & 7 & 58 \\
\hline 10 & 2015 & & 0 & 8 \\
\hline
\end{tabular}

Data Source: Regional Secretariat of Legal Section of Cianjur Regency 
IJIK, Vol. 9 No. 1: 9-22

Law Of Substance And Consistency Of Regional Regulation Number 3 Of 2006 Concerning Community

Development Activities In Karimah

Anwar

\section{CONCLUSION}

The issuance of Regional Regulation number 3 of 2006 concerning the community development movement has a morality, starting from the 2001-2006 regional head election, at that time the regional head election by the Cinajur Regency DPRD, each region had not yet elected the regional head directly, when it was followed by Ir. Wasidi Swastomo and Drs. Tjetje Muhtar Soleh, when religion was very interesting to get political support, Ir. Wasidi Swastomo promised that if he was elected, he would impose Islamic law in Cianjur regency, the election of the regional head would hold Ir. Wasidi Swastomo. The Beakhlakul Karimah Community Development Movement Program was carried out, and the Regional draft Regulation was submitted to the Cianjur Regency DPRD for Regional Regulation to be adopted, in the 2006 direct election Ir. Wasidi Swastomo and Ade Barkah Lose by the couple Drs Tjeptjep Muntar Soleh and Dadang Supianto, this Regional Regulation was passed on July 20, 2006, at the beginning of the reign of Drs Tjetjep Muntar Soleh and Dadang Supianto.

The substance and consistency of this Regional Regulation are many of the substance of this Regulation governing the movement of people with morality. The term Akhlaqul Karimah and its application are only known in terms of Islam. Non-Islamic religions do not recognize the principles contained in the Islamic religion. This Perda will be difficult to apply even considered contrary to Human Rights, especially for non-Islamic religions and not in accordance with the content of the legislation.

The effectiveness of Regional Regulation number 3 of 2006 concerning the community development movement endorsed by karimah, is the political policy of the regional head. The author can see from every legal product issued by the district government of Cianjur, Regional Regulation number 3 of 2006 is used as the legal basis for making regional legal products in its consideration. If the writer sees from the many regional legal products, both Regional Regulations, and Regents Regulations, the writer finds two regional legal products, namely 1 Regents Regulations and 1 Regional Regulations from many regional legal products issued by the Cianjur regency government. Namely Regents Regulations number 18 of 2012 concerning Empowerment of Early Education and Takmiliyah Education of the Qur'an, Regents Regents now have become Regional Regulations number 3 of 2014 concerning Empowerment of Takmiliyah Early Education and Al-Qur'an Education which embody Regional Regulations number 3 of 2006 concerning the community development movement with the morality. At the same time, other legal products are not used as a legal basis for making laws, because regulation number 3 of 2006 regulates various fields.

\section{REFERENCES}

Abdullah, A. (2019). Paradigma Dan Epistemologi Dakwah. Jurnal Pemberdayaan Masyarakat, 7(1), 19.

Arroisi, J. (2017). Sakral Dan Profan Dalam Perkembangan Ideologi Politik Agama. Tsaqafah, 13(1), 71-92.

Fauzan, P. I., \& Fata, A. K. (2018). Positivisasi Syariah Di Indonesia, Legalisasi Atau Birokratisasi? Jurnal Konstitusi, 15(3), 592-615.

Goni, R. M. M. (2015). Kewenangan Gubernur Dalam Pembentukan Peraturan Daerahsebagai Implementasi Pemberlakuan Otonomi Daerah. Lex Administratum, 3(4).

Ma'mun, M. A.-B. (2016). Islam Dan Negara: Perdebatan Dalam Pembuatan Perda Syariat Di Kota Tasikmalaya. Afkaruna: Indonesian Interdisciplinary Journal Of Islamic Studies, 12(2).

Muwahid, M. (2012). Transformasi Hukum Islam Dalam Sistem Hukum Nasional. Al-Manahij: Jurnal Kajian Hukum Islam, 6(2), 205-216. 


\section{IJIK, Vol. 9 No. 1: 9-22}

Law Of Substance And Consistency Of Regional Regulation Number 3 Of 2006 Concerning Community Development Activities In Karimah

Anwar

Nazir, M. (2011). Metode Penelitian, Cetakan Ke Tujuh. Bogor: Penerbit Ghalia Indonesia.

Rosidin, U. (2010). Otonomi Daerah Dan Desentralisasi: Dilengkapi Undang-Undang Nomor 32 Tahun 2004 Dengan Perubahan-Perubahannya. Pustaka Setia.

Sukayat, T. (2015). Internalisasi Nilai Islam Melalui Kebijakan Publik (Studi Terhadap Dakwah Struktural Program Bandung Agamis). Jurnal Dakwah, 16(1), 79-102.

Syaputra, D. (2019). Piagam Jakarta Dan Hubungannya Dengan Perdaperda Bernuansa Syari'ah. Journal Review Of Justisia, 1(2), 13-21.

Syukur, A. (2011). Islam, Etnisitas Dan Politik Identitas: Kasus Sunda. Dalam Miqot (Jurnal IlmuIlmu Keislaman), 35(2).

Zoelva, H. (2015). Fenomena Peraturan Daerah Syariaat Islam Di Daerah. Retrieved May 12, 2015, From Hamdanzoleva.Wordpress.Com Website: Http://Hamdanzoleva.Wordpress.Com/2009/01/06/ Fenomena-Peraturan-DaerahSyariaat-Islam-Di- Daerah/\#More-91 